\title{
Genetic Gain and Diversity of Orchard Crops Under Alternative Management Options in a Clonal Seed Orchard of Pinus thunbergii
}

\author{
By K. S. KANG ${ }^{1)^{*}}$, D. LindGReN ${ }^{2)}$, T. J. MulLiN ${ }^{3)}$, W.-Y. ChOI ${ }^{4)}$ and S.-U. HAN ${ }^{5)}$
}

(Received $15^{\text {th }}$ November 2004)

\begin{abstract}
Genetic gain and diversity, expressed by status number, of seed crops from a clonal seed orchard of Pinus thunbergii were estimated considering selection, fertility variation and pollen contamination, and compared for different management alternatives (selective harvest, genetic thinning and combination of both options). Management variables included the proportion of clones left after selective harvest and/or genetic thinning. The impact on genetic gain and diversity of seed crops was quantified as a function of the quantity and quality of gene flow from outside the seed orchard. Genetic gain varied with the proportion of selected or thinned clones. Genetic thinning by means of truncation selection of clones resulted in a large decrease in status number, which was accompanied by greater genetic gain than achieved by selective harvest alone. As expected, gene flow from outside the seed orchard greatly increased status number of the seed crop at higher rates of pollen contamination under all management options. The formulae and results of the present study could be used for identifying favorable selection intensity and alternatives for orchard management.
\end{abstract}

Key words: genetic gain, gene diversity, rouging, selective harvest, Japanese black pine.

\section{Introduction}

Pinus thunbergii Parl. is a diploxylon pine species known commonly as Japanese black pine. It grows predominantly along the coasts of southern Korea and Japan (Mirov, 1967) where it is presumably resistant to salt spray. It usually occurs in pure stands along the coasts and as mixed stands with $P$. densiflora further inland. One of the fast-growing maritime pines, $P$. thunbergii has been widely managed in plantations due to its high-quality timber and as windbreaks along the seacoasts in Korea. The species has been under intensive breeding program since 1959 and has resulted in the selection of 151 plus trees and the establishment of seed orchards totaling 22 ha. A total of 69 open-pollinated and 319 control-pollinated families are currently being field tested to generate progeny test estimates of parental breeding value.

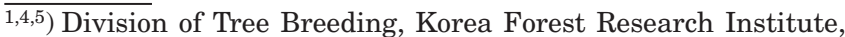
44-3 Omokcheon, Kwonsun, Suwon, Kyonggi 441-350, Republic of Korea.

2) Department of Forest Genetics and Plant Physiology, Swedish University of Agricultural Sciences, SE-901 83 Umeå, Sweden.

3) Department of Forestry, Campus Box 8002, North Carolina State University, Raleigh, NC 27695-8002, USA.

*) Author to whom all correspondence should be addressed: KYU-SuK KANG (email: kangks@foa.go.kr, tel: +82 312901120 , fax: +82 312928468 ).
The main goal of seed orchards is the production of genetically improved seeds for artificial reforestation programs. It is important to consider level of diversity in a seed orchard, even if gain in economic and/or adaptive traits is the primary goal (LINDGREN et al., 1996; KANG, 2001; GÖMÖRY et al., 2003). Inadequate genetic diversity in seed orchard crops may result in accumulation of inbreeding with its associated depression, which directly reduces potential productivity. Genetic improvement is thus defined as a process whereby genetic gain of selected attributes is improved while joint consideration is given to the genetic diversity of deployed materials (Rosvall, 1999).

There are various orchard management options to increase genetic gain while conserving genetic diversity, including selective harvesting, genetic thinning, and the combination of both (LINDGREN and EL-KASSABY, 1989; BONDESSON and LINDGREN, 1993). The practice of selective harvesting improves only the genetic contribution of seed parents, while both seed and pollen parents are improved with genetic thinning. For the production of improved seeds, many factors such as clonal genetic value, selection intensity, fertility variation and pollen contamination should be considered.

The objectives of this study were: 1) to evaluate the genetic gain and diversity of seed crops from a $P$. thunbergii clonal seed orchard under different management options; and 2) to determine appropriate selection intensity (i.e., seed collection proportion, thinning rate) in selective harvest and genetic thinning. Additionally, the effects of gene migration from outside the orchard on genetic gain and diversity, and the consequences of alternative management options for seed production are also discussed.

\section{Materials and Methods}

\section{Seed orchard description}

The clonal seed orchard of $P$. thunbergii is located on An-myun island, in the western part of Korea (lat. $36^{\circ}$ $3^{\prime} \mathrm{N}$, long. $126^{\circ} 2^{\prime} \mathrm{E}$ and alt. $35 \mathrm{~m}$ ) and established in 1980. The orchard is 12 hectares, with approximately equal numbers of grafts from 109 field-selected plustrees, planted at $5 \mathrm{~m} \times 5 \mathrm{~m}$ spacing. A genetic thinning is planned for the seed orchard at age 25 years, based primarily on clonal breeding values derived from the species progeny tests. Clonal fertility was estimated from assessments of strobilus production over nine consecutive years (data not shown), and used for the calculation of status number (LINDGREN and MULLIN, 1998; KANG and LindGREN, 1999). Six ramets per clone were chosen randomly for assessment, avoiding trees growing 
at the edge. The number of female strobili was counted individually over the whole crown. The number of male strobili was estimated by multiplying the average strobilus number per branch by the total number of branches bearing male strobili.

Additive genetic values for each orchard-parent genotype were obtained from open-pollinated progeny tests (represented by general combining ability, GCA). Parental GCA values for volume growth at age 12 were estimated by the method of best linear unbiased prediction (BLUP), based on height and diameter at breast height measured from field trials (manuscript in preparation).

\section{Genetic gain and diversity}

Genetic value $(G)$ and diversity (status number, $N_{s}$ ) of seed crops were estimated under four management alternatives, as follows:

1) Alternative 1: selective seed harvest from the best $50 \%$ of clones, without genetic thinning

$$
G=0.5 i_{\left(X_{f}, N\right)} \sigma_{A}+M C \quad N_{s}=\frac{4 N N_{f}}{\Psi\left[N+(1-2 M)(3-2 M) N_{f}\right]}
$$

2) Alternative 2: $50 \%$ genetic thinning, removing clones with inferior genetic values

$$
G=(1-M) i_{\left(V_{f}, N\right)} \sigma_{A}+M C \quad N_{s}=\frac{N_{f}}{(1-M)^{2} \Psi}
$$

3) Alternative 3: $\mathbf{7 5 \%}$ genetic thinning, a more intensive genetic thinning than used in Alternative 2

4) Alternative 4: $20 \%$ selective harvest after $\mathbf{5 0 \%}$ genetic thinning

$$
G=\frac{\left(i_{\left(N_{f}, N\right)}+(1-2 M) i_{\left(N_{m}, N\right)}\right) \sigma_{t}}{2}+M C \quad N_{s}=\frac{4 N_{f} N_{m}}{\Psi\left[N_{m}+\left(3-8 M+4 M^{2}\right) N_{f}\right]}
$$

where: $i$ is selection intensity; $\sigma_{\mathrm{A}}$ is additive genetic variance; $M$ is gene migration; $C$ is inferiority of contaminating pollen; $N$ is the census number; $N_{f}$ is the number of seed parents and $N_{m}$ is the number of pollen parents (c.f., LINDGREN and MULLIN, 1998). $\Psi$ is the sibling coeffi- cient describing fertility variation among clones (see also KANG and LINDGREN, 1999).

\section{Input values}

In this study, the genetic values of orchard clones were expressed in standard units with a mean of zero and additive genetic standard deviation, $\sigma_{\mathrm{A}}=1$. Values chosen for consideration of gene migration $(M)$ were $15 \%$ and $0 \%$, meaning that pollen contamination rates were $30 \%$ and $0 \%$, respectively (ADAMS and BURCZYK, 1998). Orchard pollen is expected to be genetically better than that from the wild forest; the inferiority of contaminating pollen $(C)$ was therefore considered to be one additive standard deviation below that of seed orchard clones (i.e., $C=-1$ ). It was assumed that genetic value and seed production were independent traits.

Fertility is the ability to produce successful gametes. In this study, fertility is expressed as an individual's relative number of successful gametes (GREGORIUS, 1989). Fertility variation $(\Psi)$ was set at 2 , a commonly reported value for clonal seed orchards (KANG et al., 2003a), equivalent to $100 \%$ coefficient of variation $(C V)$ in gamete contributions among clones (e.g., seed production).

\section{Results}

Selective seed harvest (Alternative 1), genetic thinning (Alternatives 2 and 3) and the combination of both options (Alternative 4) increased genetic gain over the initial orchard condition (i.e., before thinning) (Table 1). The increase was, however, coupled with a decrease in status number. Genetic gain was highest and diversity (status number) lowest in Alternative 3 under both gene migration scenarios.

Pollen contamination affected both genetic gain and diversity. With no pollen contamination, all alternatives showed higher genetic value but lower status number, compared to the scenario with pollen contamination. Before thinning (Alternative 1), a gene migration rate of $15 \%$ increased the status number of the orchard crop by

Table 1. - Census number $(N)$, genetic value $(G)$ and status number $\left(N_{s}\right)$ under various

\begin{tabular}{|c|c|c|c|c|c|c|c|}
\hline \multirow{2}{*}{\multicolumn{2}{|c|}{$\begin{array}{c}\text { Management } \\
\text { options }\end{array}$}} & \multicolumn{2}{|c|}{$N$} & \multicolumn{2}{|c|}{$M=15 \%$} & \multicolumn{2}{|c|}{$M=0 \%$} \\
\hline & & $\begin{array}{l}\text { Before } \\
\text { thinning }\end{array}$ & $\begin{array}{c}\text { After } \\
\text { thinning }\end{array}$ & $G$ & $N_{s}{ }^{\mathrm{b})}$ & $G$ & $N_{s}^{\mathrm{b})}$ \\
\hline \multicolumn{2}{|c|}{ Alternative 1} & 109 & 109 & 0.242 & $56.3(0.52)$ & 0.392 & $43.8(0.40)$ \\
\hline$"$ & 2 & 109 & 55 & 0.517 & $38.1(0.35)$ & 0.785 & $27.5(0.25)$ \\
\hline$"$ & 3 & 109 & 27 & 0.926 & $18.7(0.17)$ & 1.266 & $13.5(0.12)$ \\
\hline$"$ & 4 & 109 & 55 & 0.816 & $25.1(0.23)$ & 1.083 & $20.0(0.18)$ \\
\hline
\end{tabular}
management options; different gene migration $(M)$ and fertility variation $(\Psi=2)$ in a clonal seed orchard Pinus thunbergii.

a) Alternatives: 1) selective seed harvest from the best $50 \%$ of clones (without genetic thinning), 2) $50 \%$ genetic thinning, removing inferior clones, 3) $75 \%$ genetic thinning, 4) $20 \%$ selective harvest after $50 \%$ genetic thinning.

b) Relative status number $\left(=N_{s} / N\right)$ in parentheses. 


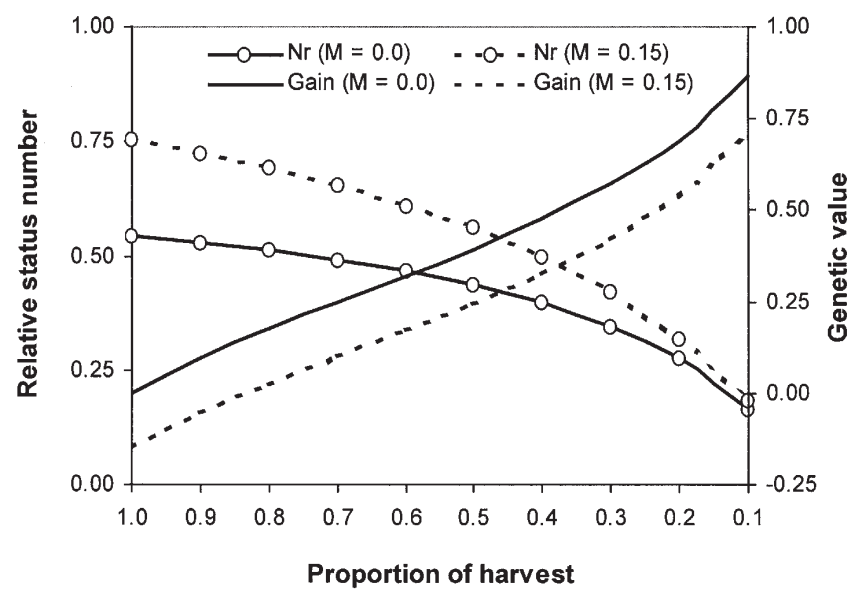

Figure 1. - Relationship between genetic value and relative status number $\left(N_{r}\right)$ for selective harvest from seed parents, with different levels of gene migration $(M)$. In these examples, fertility variation $(\Psi)$ was set to 2 and contamination inferiority $(C)$ equal to -1 .

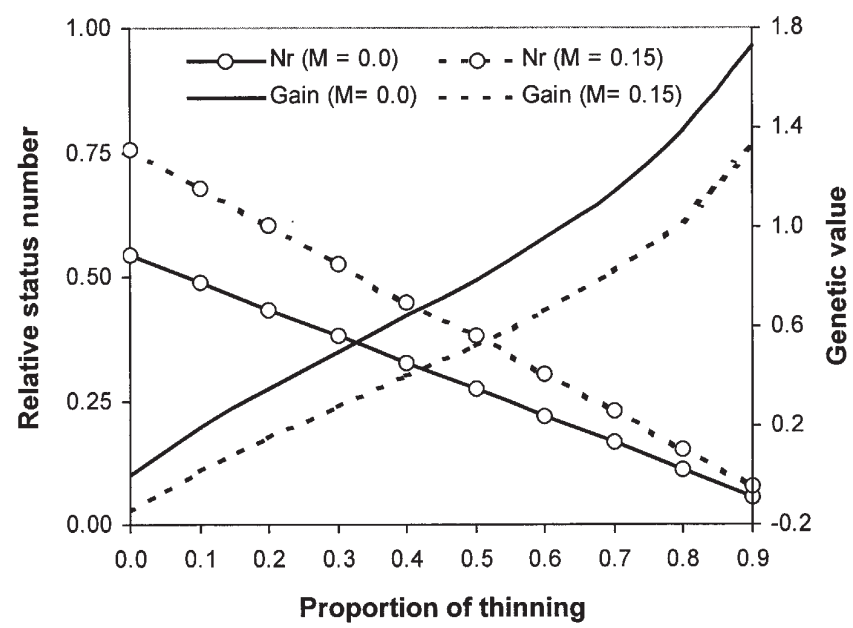

Figure 2. - Relation between genetic value and relative status number $\left(N_{r}\right)$ for genetic thinning, with different levels of foreign gene migration $(M)$. In these examples, fertility variation $(\Psi)$ was set to 2 and contamination inferiority $(C)$ equal to -1 .

$22.2 \%$, but after genetic thinning, regardless of intensity (Alternatives 2 and 3), the same level of gene migration raised the status number by $27.8 \%$ (Table 1 ).

Relative gain from orchard management varied with the proportion of selected and/or thinned clones (Figs. 1 and 2). The increase in genetic value was not linear relative to the proportion of selected and/or thinned clones in selective harvest and genetic thinning options. Genetic thinning gave greater gain than selective harvest at the same intensity, but this was accompanied by a greater loss of status number.

\section{Discussion}

In Alternative 1 (selective harvest without genetic thinning), seeds are collected only from clones with higher genetic values, while the entire orchard remained intact. Selection is only for the seed parents, and not for pollen parents. Under genetic thinning options (Alternatives 2 and 3), seeds are harvested from all of the remaining clones after thinning; thus, as opposed to Alternative 1, both pollen and seed parents are improved by the irreversible removal of clones with lower genetic values. The remaining selected clones contribute to the seed crop as both male and female parents. Selection, therefore, occurs for both parents at the same time and with the same intensity.

In Alternative 4, all clones remaining after the $50 \%$ genetic thinning serve as the pollen source, while seeds are harvested from a subset of clones consisting of the top $20 \%$ with the highest genetic value. Thus, selection occurs twice; the first is simultaneous selection against inferior clones (pollen and seed parents) at the time of thinning, and the second is the selection against the subset of the remaining clones acting as seed parents only (see the formula in Methods and Materials).

Genetic thinning gave greater gain than selective harvest at the same selection intensity. Thus, $50 \%$ genetic thinning (Alternative 2) could be applicable immediately in this seed orchard. For the long run, however, $75 \%$ genetic thinning (Alternative 3) would be recommended to achieve greater gain for volume growth and better spacing for seed production.

Strong genetic thinning (e.g., Alternative 3) would remove many clones and subsequently result in a substantial loss of diversity. However, the combination of genetic thinning and selective harvest would be better than selective harvest alone, because the usual purpose of a seed orchard is to obtain maximum gain with some appropriate level of genetic diversity (COTTERILL and JACKSON, 1989; LINDGREN and EL-KASSABY, 1989). Under management Alternative 4, the status number of the crop still exceeds 20 , which seems reasonable given that 20 tested clones are commonly recommended for new orchard establishment in existing programs (e.g., NCSU, 2001).

The potential quantity of seed production may decrease in the short term when the orchard is thinned more heavily. However, seed production will recover in a few years as tree crowns develop and occupy the openings created by tree removal (KANG et al., 2003b). There have been many reports that there is much variation in strobili production among clones in seed orchards and that reproductive characteristics are under strong genetic control (GRIFFIN, 1982; EL-KASSABY et al., 1989; KJÆR, 1996; GÖMÖRY et al., 2000). Seed production could thus be included as one of the selection criteria for clones retained in the orchard. However, negative genetic correlation between reproductive output and vegetative growth should be considered when the seed production is include as a selection criterion (EL-KASSABY and BARCLAY, 1992). Also, a survey of changes in seed production and effective number before- and after-genetic thinning may be needed to secure sufficient seed supply, and used as a means to select for seed production.

This paper reports on different alternatives for seed orchard management to increase genetic gain while maintaining adequate levels of genetic diversity. The results indicated that genetic gain and diversity might vary considerably depending on clonal genetic value, selection intensity, gene migration and fertility varia- 
tion. The techniques developed can assist orchard managers to impose selection intensity that achieves an appropriate balance of genetic gain and diversity in orchard crops. Finally, seed demand and the impact of tree removal on immediate and long-term seed yield should be also considered.

\section{Acknowledgements}

This work was funded by the Korea Forest Research Institute. The authors gratefully thank Mr. JANG, K.W. for collection of fertility data and for performance of genetic thinning operations in the orchard.

\section{References}

ADAms, W. T. and J. Burczyk (1998): Magnitude and implications of gene flow in gene conservation reserves. p.1-16 in Forest conservation genetics: Principles and practice. BoYle, T., et al. (eds.). CIFOR Australia.

Bondesson, L. and D. LindGREN (1993): Optimal utilization of clones and genetic thinning of seed orchards. Silvae Genet. 42: 157-163.

CotTERILl, P. P. and N. JACKSON (1989): Gains expected from clonal orchards under alternative breeding strategies. For. Sci. 35(1): 183-196.

El-KASSABY, Y. A. and H. J. BARCLAY (1992): Cost of reproduction in Douglas-fir. Can. J. Bot. 70: 1429-1432.

EL-Kassaby, Y. A., A. M. K. FAshler and M. CRown (1989): Variation in fruitfulness in a Douglas-fir seed orchard and its effect on crop management decisions. Silvae Genet. 38: 113-121.

GRIFFIN, A. R. (1982): Clonal variation in radiata pine seed orchards. I. Some flowering, cone and seed production traits. Aust. For. Res. 12: 295-302.

GREGORIUS, H. (1989): Characterization and analysis of mating system. Ekopan Verlag, Germany. 158 p.

GÖMÖRY, D., R. BRUCHANIK and R. LONGAUER (2003): Fertility variation and flowering asynchrony in Pinus sylvestrys: consequences for the genetic structure of progeny in seed orchards. For. Ecol. Manage 174: 117-126.
GÖMÖRY, D., R. BRUCHANIK and L. PAUlE (2000): Effective population number estimation of three Scots pine (Pinus sylvestris L.) seed orchards based on an integrated assessment of flowering, floral phenology, and seed orchard design. For. Genet. 7: 65-75.

KANG, K. S. (2001): Genetic gain and gene diversity of seed orchard crops. Acta Universitatis Agriculturae Sueciae, Silvestria 187. 75 p.

Kang, K.S. and D. Lindgren, 1999: Fertility variation among clones of Korean pine (Pinus koraiensis S. et Z.) and its implications on seed orchard management. For. Genet. 6: 191-200.

Kang, K. S., A. D. Bila, A. M. HarJu and D. Lindgren (2003a): Fertility variation in forest tree populations. Forestry 76: 329-344.

Kang, K. S., Y. A. El-Kassaby, W. Y. Choi, S. U. Han and C. S. KIM (2003b): Changes in genetic gain and diversity caused by genetic thinning in a clonal seed orchard of Pinus densiflora. Silvae Genet. 52: 220-223.

KJÆR, E. D. (1999): Sustainable use of forest genetic resources. Ph. D. Thesis. Royal Veterinary and Agriculture University, Horsholm, Denmark, $67 \mathrm{p}$.

LindGREN, D. and Y. A. El-Kassaby (1989): Genetic consequences of combining selective cone harvesting and genetic thinning in clonal seed orchards. Silvae Genet. 38: $65-70$.

LindGREN, D. and T. J. Mullin (1998): Relatedness and status number in seed orchard crops. Can. J. For. Res. 28: $276-283$.

Lindgren, D., L. GEA and P. JefFerson (1996): Loss of genetic diversity monitored by status number. Silvae Genet. 45: 52-59.

Mirov, N. T. (1967): The genus Pinus. The Roland Press Company, New York. p. 261-297.

NCSU (2001): NC State University-Industry Cooperative Tree Improvement Program. 45 ${ }^{\text {th }}$ annual report. Department of Forestry, College of Forest Resources, NC State University, Raleigh, NC. 34 p.

Rosvall, O. (1999): Enhancing gain from long-term forest tree breeding while conserving genetic diversity. Acta Universitatis Agriculturae Sueciae, Silvestria 109, Umeå, Sweden, 65 p.

\title{
Genetic Variation and Realized Genetic Gain From Black Pine Tree Improvement
}

\author{
By D. MATZIRIS*)
}

(Received $15^{\text {th }}$ November 2004)

\section{Summary}

In 1978 a 10 ha clonal seed orchard of black pine (Pinus nigra Arnold) was established in the area of Koumani in the western part of Peleponnesos, Greece. The orchard comprises 52 clones derived from intensive-

\footnotetext{
*) Forest research Institute, Athens Greece.

Present Address: Antifilou 46, 15771, Athens Greece
}

ly selected plus trees in the natural forest of black pine of Peloponnesos. In 1991 three open pollinated progeny tests were established in Peloponnesos, proximal to the villages of Raches, Vlachokerasia and Vamvakou. Seedlings from 52 families including a commercial check (CC) were planted in each one of the three locations. Assessments were made when the trees were 4,7 and 9 years respectively, with the following results. 